\title{
The study of the drying kinetic and the cutting performance in dried betel nut production machine
}

\author{
Naruebodee Srisang ${ }^{1, *}$, Siriwan Srisang ${ }^{1}$, and Thatchapol Chungcharoen ${ }^{1}$ \\ ${ }^{1}$ Department of Engineering, King Mongkut's Institute of Technology Ladkrabang, Prince of Chumphon Campus, Chumphon, Thailand
}

\begin{abstract}
Betel nut kernel is an important raw material in the leather and dye industries. The quality control after harvest is necessary, especially, the excess moisture content may cause the spoilage. Therefore, this research aims to study the betel nut fruit drying using infrared ray combined with the rotated trays. The betel nuts fruits were placed in rotated trays. These trays were installed within drying chamber which had the infrared rod in 2 positions namely the center and wall of drying chamber. The drying temperature used at 80,100 and $120^{\circ} \mathrm{C}$. The revolution speed of tray was set at 2,4 and $6 \mathrm{rpm}$. The dried betel nut fruits were cut into 2 pieces at the blade speed of 25,30 and $35 \mathrm{rpm}$. The experimental results showed the installation of infrared rods at the center could decrease the moisture content faster than at the wall. The betel nut fruit should use the drying temperature of $120^{\circ} \mathrm{C}$ for $10 \mathrm{~h}$ and the revolution speed of $2 \mathrm{rpm}$. The blade speed of $30 \mathrm{rpm}$ gave the most cutting performance about $76 \%$. The colour of dried betel nut kernel ( $\mathrm{L}^{*}, \mathrm{a}^{*}$ and $\left.\mathrm{b}^{*}\right)$ did not significantly difference with the commercial betel nut.
\end{abstract}

\section{Introduction}

Betel nut (Areca Catechu Linn.) also called as areca nut and widely plant for agricultural product in Chumphon province. Betel nut kernel has been widely used in medicine application including paint and leather manufacturing [1]. Moreover, betel nut kernel has been researched to extract the peroxidase as the major protein constituent in betel nut kernel to apply for useful in cancer therapy [2]. Generally, betel nut fruit is dried with sunlight around 3 weeks to reduce the moisture content. The dried betel nut fruit is cut with knife to easy separate kernel and husk. Then, the betel nut kernel is again dried with sunlight about 7 days to obtain the moisture content around $12-15 \%$ (d.b.). Kulanthaisami et al. [3] accounted the dried betel nut kernel should be reduced the moisture content to $13 \%$ (d.b.) before storage. The moisture content may be decreased to lower than $12 \%$ (d.b.) which depended on the husking or cutting process in next step. Jarimops et al. [1] reported the optimal moisture content of dried betel nut fruit about 6\% (d.b.) before the husking using squeeze method. Subsequently, the requirement of low moisture content caused the increase of energy usage and production time. The long time in manufacturing process and the difficulty in quality control those were undesired for dried betel nut producer.

Hence, the objective of this work aims to study the betel nut fruit drying using the infrared ray combined with the revolved tray. The dried betel nut fruit after drying that was cut into 2 pieces using the cutting blade unit. The effect of drying temperature and the revolution speed of tray on the drying kinetic were investigated. The cutting performance for each the revolution speed of blade was reported. The quality of dried betel nut kernel was inspected in term of the colour.

\section{Materials and methods}

Betel nut fruits are mature which obtained from Chumphon province by they had the orange skin and brown kernel as shown in Fig. 1. Diameter of betel nut fruit was in the range of $3-5 \mathrm{~cm}$ and the average mass as $47.15 \mathrm{~g}$. The betel nut fruits were dried using infrared drying combined with rotated trays. The betel nut fruit had the average of initial moisture content about $150 \%$ (Dry basis, d.b.). These betel nut fruits about 90 fruits were put in the cylindrical trays (8 trays) which were installed in drying chamber as represented in Fig. 2. These trays were driven by $1 \mathrm{HP}$ motor and revolved around the revolution core at the revolution speed of 2, 4 and $6 \mathrm{rpm}$. The size of drying chamber was $0.7 \times 0.7 \times 0.98 \mathrm{~m}^{3}$. Inside drying chamber had the number of infrared lamp about 3 lamps by each infrared lamp about $1000 \mathrm{~W}$. This research studied the infrared lamp installation in 2 places namely the wall and the center of drying chamber. For the installation on wall, a one infrared lamp was installed on each beside wall of drying chamber. On the other hand, in case the installation at center of drying chamber, three infrared lamps were set at the center chamber. The betel nut fruits in trays were dried at temperature of 80,100 and $120^{\circ} \mathrm{C}$ simultaneously with the revolution of trays at predetermined time. The weight of betel nut fruit in each drying time was recorded to calculate the moisture content. The final moisture content of betel nut fruit desired about $15 \%$ (d.b.). The moisture determination was repeated and reported in the average value.

Corresponding author: naruebodee.sr@kmitl.ac.th 
The dried betel nut fruits were transported to the cutting blade unit that drove by 2 HP motor as displayed in Fig. 3. The revolution velocity of blade was 25, 30 and $35 \mathrm{rpm}$. The efficiency of betel nut fruit cutting was estimated from equation (1): [1]

$$
\text { Cutting performance }(\%)=[(F+0.5 U) \times 100 / N] \times 100
$$

Where $F$ is the number of betel nut fruit which can be completely cut by blade unit, $U$ is the number of betel nut fruit which can not completely cut by blade unit and $N$ is the total number of betel nut fruit which is fed to blade unit.

Moreover, the colour of betel nut kernel was measured using Konica Minolta Charoma Meter CR-400. The colour value was reported in the form of $\mathrm{L}^{*}, \mathrm{a}^{*}$ and $\mathrm{b}^{*}$. Moreover, the change of betel nut kernel colour was displayed by the $\Delta \mathrm{E}$ value as calculated in equation (2)

$$
\Delta E=\left[\left(\Delta L^{*}\right)^{2}+\left(\Delta a^{*}\right)^{2}+\left(\Delta b^{*}\right)^{2}\right]^{1 / 2}
$$

Where $\Delta \mathrm{L}^{*}$ is the difference of the $\mathrm{L}^{*}$ value between sample and betel nut kernel before drying, $\Delta \mathrm{a}^{*}$ is the difference of the $a^{*}$ value between sample and betel nut kernel before drying and $\Delta b^{*}$ is the difference of the $b^{*}$ value between sample and betel nut kernel before drying. All samples were duplicated and the average value from the repetition was reported.

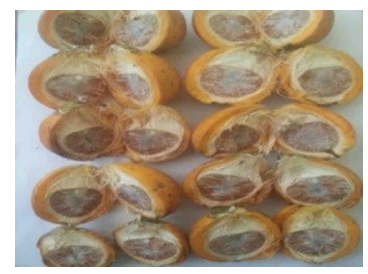

Fig. 1. Betel nut fruit.

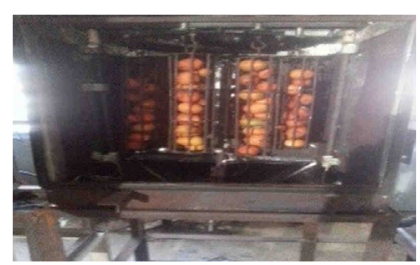

Fig. 2. Betel nut fruits in rotated trays.

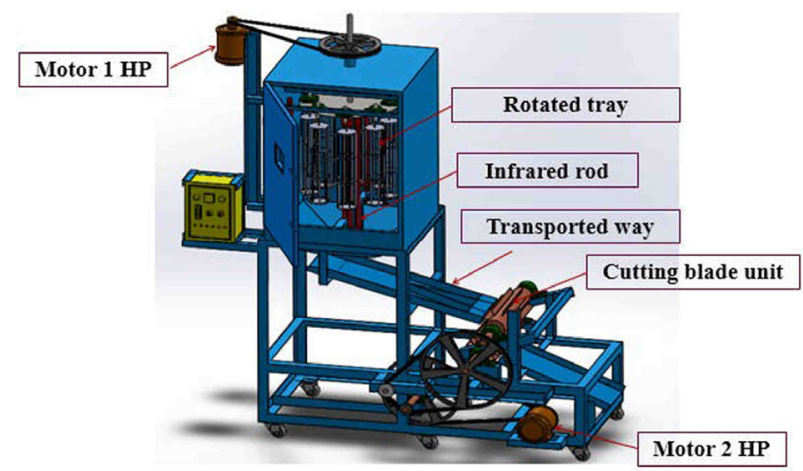

Fig. 3. Infrared dryer and cutting blade unit.

\section{Results and discussion}

\subsection{Drying kinetic}

The effect of the different infrared positions, i.e., the wall and the center of drying chamber on the drying kinetic of betel nut fruit as represented in Fig. 4, 5 and 6. The betel nut fruit was dried using the infrared drying at the temperature of 80,100 and $120^{\circ} \mathrm{C}$ combined with the rotated trays. These trays revolved at the revolution velocity of 2, 4 and $6 \mathrm{rpm}$. Results exhibited that the initial moisture content about $150 \%$ (d.b.) rapidly decreased in the first period drying. Because of the infrared ray is a magnetic wave which does not use the medium for the heat transmission. Therefore, at the first period drying around $4 \mathrm{~h}$, the betel nut fruit in rotated trays directly obtained the heat from the infrared ray and the partial ray penetrated and stimulated the diffusion of moisture from interior to exterior [4]. Then, the moisture evaporated from the surface of betel nut fruit. These incidents caused the rapid moisture removability.

When the further drying time, the moisture content gradually diminished to the final moisture content of $15 \%$ (d.b.). The moisture content slowly decremented due to the moisture movement in diffusion form slower than the evaporation form [5]. The drying time was in the range of 32-44, 18-24 and 10-14 $\mathrm{h}$ for the drying temperature of 80,100 and $120^{\circ} \mathrm{C}$, respectively. The reduction rate of moisture augmented with the enhanced drying temperature and resulted in the drying time shortened by it spent the shortest drying time for $10 \mathrm{~h}$ at temperature of $120^{\circ} \mathrm{C}$ and the revolution speed of tray about $2 \mathrm{rpm}$. The increased drying temperature that provoked the moisture diffusion within betel nut fruit. Jing et al. [6] and Saniso et al. [7] reported those the increment of diffusion coefficient with the increased drying temperature and resulted in the amelioration of moisture transfer.

The infrared position affected the drying kinetic of betel nut fruit by the infrared installation at the center of drying chamber gave the higher drying rate than the wall installation. This result may cause from the infrared installation at the center can considerably distribute the heat in around direction whereas the wall installation had the partial heat loss to the wall. The effect of infrared position did not clearly appear at the drying temperature of $80^{\circ} \mathrm{C}$. However, this effect had obviously influenced when the increased drying temperature to $120^{\circ} \mathrm{C}$ as shown in Fig. 6.

The moisture reduction rate of betel nut fruit increased with the decrement of the revolution speed of tray. The tray speed of $2 \mathrm{rpm}$ obtained the higher moisture reduction rate than the tray speed of 4 and $6 \mathrm{rpm}$ as displayed in Fig. 4, 5 and 6. This result may be explained by the lower tray speed can regularly and continuously get the heat when collated with the higher tray speed. 


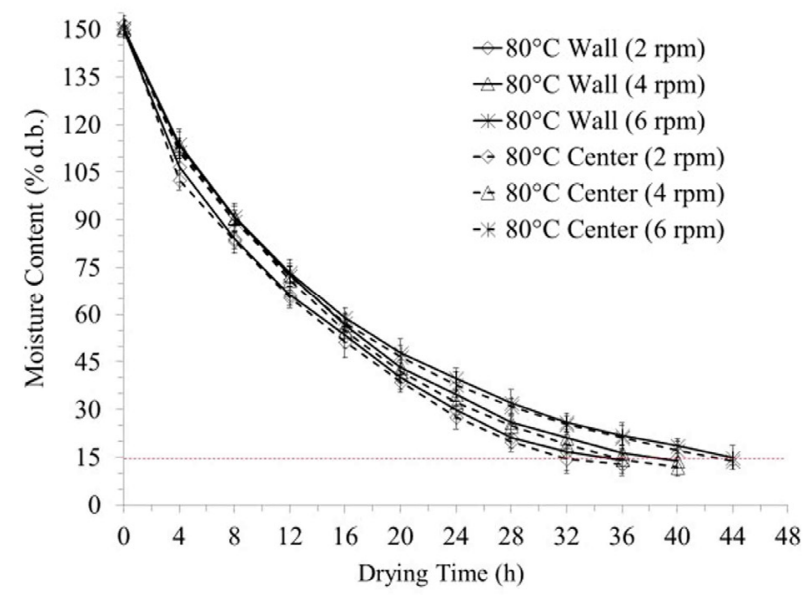

Fig. 4. Effect of different infrared positions (the wall and center of drying chamber) on the drying kinetic of betel nut fruit at drying temperature of $80^{\circ} \mathrm{C}$.

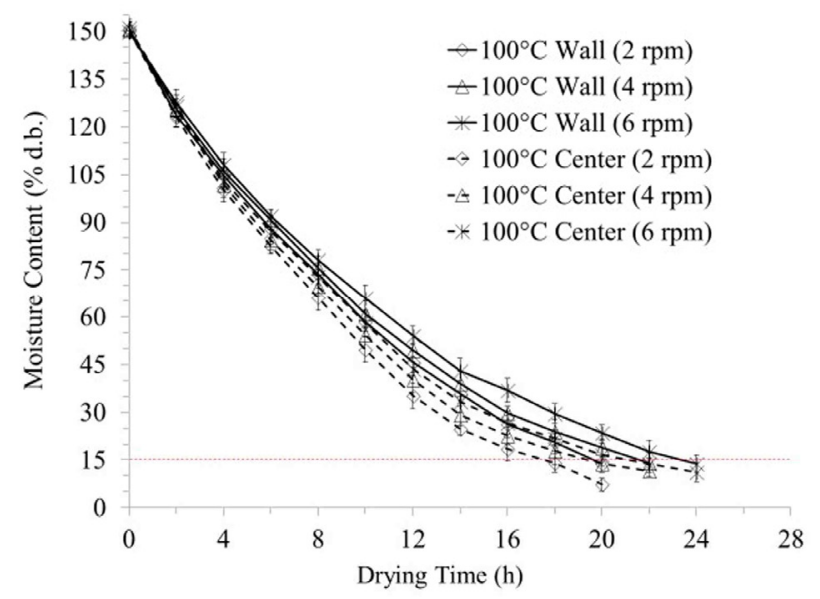

Fig. 5. Effect of different infrared positions (the wall and center of drying chamber) on the drying kinetic of betel nut fruit at drying temperature of $100^{\circ} \mathrm{C}$.

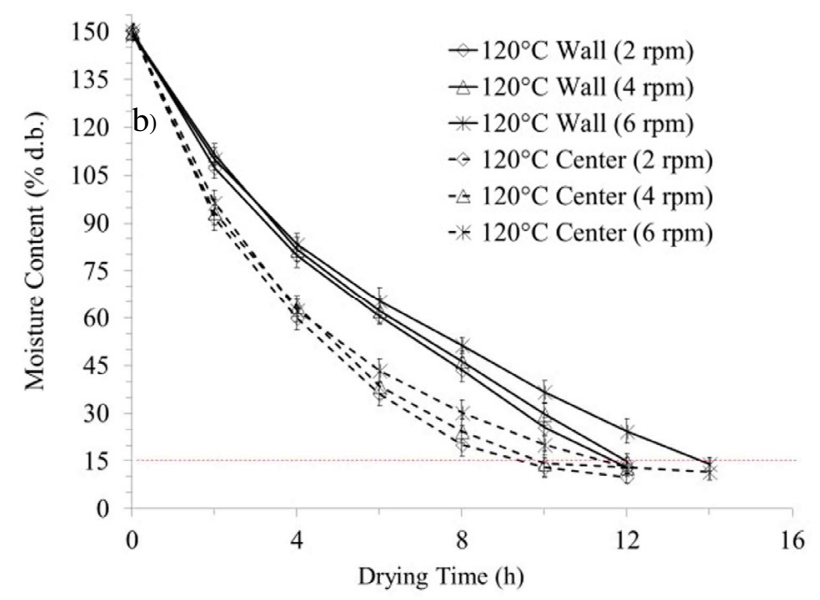

Fig. 6. Effect of different infrared positions (the wall and center of drying chamber) on the drying kinetic of betel nut fruit at drying temperature of $120^{\circ} \mathrm{C}$.

\subsubsection{Colour of betel nut kernel}

Colour of betel nut kernel after drying that significantly changed as compared with the betel nut kernel before drying by the $L^{*}$ value essentially increased while the $a^{*}$ and $b^{*}$ value significantly decreased as presented in Table 1. Tirawanichakul et al. [10] reported the pennywort colour significantly changed after infrared drying.

The change of colour of betel nut kernel was indicated by the $\Delta \mathrm{E}$ value. The betel nut kernel colour after drying contrasted with the betel nut kernel before drying as shown by the $\Delta \mathrm{E}$ value significantly increased in the range of 18.79-19.99. However, the $\Delta \mathrm{E}$ value of betel nut kernel colour after drying was insignificantly different as compared with commercial betel nut kernel. This result implied the betel nut kernel colour after infrared drying combined with rotated trays that was in the acceptable level in betel nut trade.

Table 1. Colour of betel nut kernel

\begin{tabular}{|c|c|c|c|c|}
\hline \multirow{2}{*}{ Sample } & \multicolumn{4}{|c|}{ Colour } \\
\hline & $\mathrm{L}^{*}$ & $a^{*}$ & $b^{*}$ & $\Delta \mathrm{E}$ \\
\hline $\begin{array}{l}\text { Betel nut } \\
\text { kernel before } \\
\text { drying }\end{array}$ & $\begin{array}{c}39.13 \\
\pm 0.98^{\mathrm{a}}\end{array}$ & $\begin{array}{r}9.35 \\
\pm 0.64^{c}\end{array}$ & $\begin{array}{r}17.69 \\
\pm 0.49^{c}\end{array}$ & $\begin{array}{c}0 \\
\pm 0.00^{\mathrm{a}}\end{array}$ \\
\hline $\begin{array}{l}\text { Commercial } \\
\text { dried betel nut } \\
\text { kernel }\end{array}$ & $\begin{array}{r}57.70 \\
\pm 1.69^{\mathrm{c}}\end{array}$ & $\begin{array}{c}5.16 \\
\pm 1.66^{\mathrm{b}} \\
\end{array}$ & $\begin{array}{r}12.82 \\
\pm 2.05^{\mathrm{a}} \\
\end{array}$ & $\begin{array}{r}19.81 \\
\pm 2.32^{\mathrm{b}}\end{array}$ \\
\hline $\begin{array}{c}80^{\circ} \mathrm{C}(2 \mathrm{rpm} \\
30 \mathrm{rpm})\end{array}$ & $\begin{array}{r}57.58 \\
\pm 0.97^{\mathrm{c}}\end{array}$ & $\begin{array}{c}4.95 \\
\pm 0.26^{\mathrm{ab}}\end{array}$ & $\begin{array}{r}14.28 \\
\pm 0.72^{\mathrm{b}}\end{array}$ & $\begin{array}{r}19.31 \\
\pm 1.51^{b}\end{array}$ \\
\hline $\begin{array}{c}100^{\circ} \mathrm{C}(2 \mathrm{rpm}, \\
30 \mathrm{rpm})\end{array}$ & $\begin{array}{r}56.52 \\
\pm 0.99^{b}\end{array}$ & $\begin{array}{c}4.25 \\
\pm 0.49^{\mathrm{a}}\end{array}$ & $\begin{array}{r}13.07 \\
\pm 1.60^{\mathrm{a}}\end{array}$ & $\begin{array}{r}18.79 \\
\pm 1.63^{\mathrm{b}}\end{array}$ \\
\hline $\begin{array}{c}120^{\circ} \mathrm{C}(2 \mathrm{rpm}, \\
30 \mathrm{rpm})\end{array}$ & $\begin{array}{r}57.74 \\
\pm 0.72^{c}\end{array}$ & $\begin{array}{c}4.61 \\
\pm 0.26^{\mathrm{ab}}\end{array}$ & $\begin{array}{r}12.26 \\
\pm 0.72^{\mathrm{a}}\end{array}$ & $\begin{array}{r}19.99 \\
\pm 1.13^{\mathrm{b}}\end{array}$ \\
\hline
\end{tabular}

$a, b, c$ mean with different superscripts in the same column are significantly different $(\mathrm{p} \leq 0.05)$.

Above results were considered to use in the suitable condition selection for drying, that is, the revolution speed of tray and the installation position of infrared. To reduce the rapid moisture content and keep the colour quality, hence, the revolved tray speed used $2 \mathrm{rpm}$ and the infrared rods were installed at the center of drying chamber.

\subsection{Cutting performance}

The cutting performance estimated from the betel nuts fruit got from the infrared drying at the tray speed of 2 $\mathrm{rpm}$ and the temperature of $120^{\circ} \mathrm{C}$ by the infrared rods were installed at the middle drying chamber. Then, the dried betel nut fruits at the moisture content around $15 \%$ (d.b.) were transported to the cutting blade unit and were cut at the blade velocity of 25,30 and $35 \mathrm{rpm}$. Results showed the trend of cutting performance increased when the blade speed expanded from 25 to $30 \mathrm{rpm}$ as presented in Table 2. On the other hand, the cutting performance diminished when the blade speed was excess $30 \mathrm{rpm}$. The above results indicated that the dried betel nut fruits should be cut at the blade speed of $30 \mathrm{rpm}$ to obtain the 
most cutting performance about $76 \%$. The excess blade speed may diminish the contact capability between blade and betel nut. However, the cutting performance in this research that corresponded with the result of Meein et al. [8] and Parathong [9]. Their results showed the cutting performance in the range of $75-90 \%$.

The aspect of betel nut kernel after cutting as displayed in Fig. 7a that had a little crack and its aspect resembled with the commercial betel nut kernel as shown in Fig. $7 b$.

Table 2. Average cutting performance of blade unit

\begin{tabular}{cccc}
\hline $\begin{array}{c}\text { Drying } \\
\text { temperature } \\
\left({ }^{\circ} \mathrm{C}\right)\end{array}$ & $\begin{array}{c}\text { Tray } \\
\text { speed } \\
(\mathrm{rpm})\end{array}$ & $\begin{array}{c}\text { Blade } \\
\text { speed } \\
(\mathrm{rpm})\end{array}$ & $\begin{array}{c}\text { Cutting } \\
\text { performance } \\
(\%)\end{array}$ \\
\hline \multirow{2}{*}{120} & 2 & 25 & 70.33 \\
\cline { 3 - 4 } & 2 & 30 & 76.67 \\
\hline
\end{tabular}

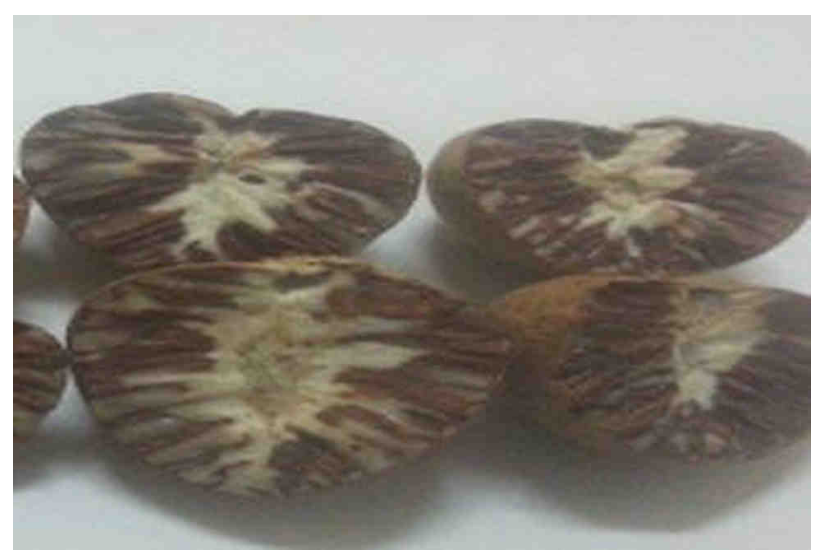

a)

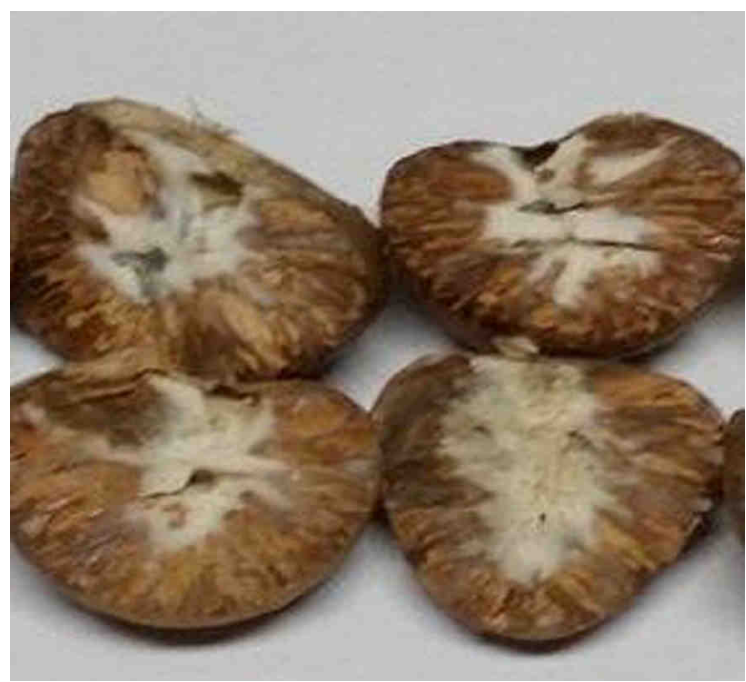

b)

Fig. 7. Aspect of a) betel nut kernel after cutting using blade unit and b) commercial betel nut kernel.

\section{Conclusions}

The betel nut fruit drying using the infrared ray combined with the revolved tray should use the drying temperature of $120^{\circ} \mathrm{C}$, the revolution speed of tray about $2 \mathrm{rpm}$ and the rotation speed of cutting blade of $30 \mathrm{rpm}$. These conditions gave the high quantities of drying rate and cutting performance, including the colour quality of betel nut kernel was in the acceptable level as compared with commercial betel nut kernel.

The authors express the sincere appreciation to the King Mongkut's Institute of Technology Ladkrabang for supporting the research fund (income research fund 2558-0208009).

\section{References}

1. B. Jarimopas, S. Niamhom, A. Terdwongworakul, Biosystems Engineering 102, 83-89 (2009)

2. Y.C. Liu, C.J.Chen, M.R. Lee, M. Li, W.T. Hsieh, J.G. Chung, H.C.Ho, Evidence-Based Complementary and Alternative Medicine 2013, 1 -12 (2013)

3. S. Kulanthaisami, P. Subramanian, P. Venkatachalam, A. Sampathrajan, Madras Agric. J. 94, 7-12 (2007)

4. N. Meeso, A. Nathakaranakule, T. Midhiyonon, $\mathrm{S}$. Soponronnarit, Journal of Food Engineering 78, 1248-1258 (2007)

5. S. Tirawanichakul, S. Lamaepae, Y Tirawanichakul, Burapha Science Journal 17, 117-129 (2012)

6. L. Jing, T.Zhaosheng, L. Haijun, W. He, Int. J. Agric. \& Biol. Eng. 10, 302-311 (2017)

7. E. Saniso, F. Saudi, R. Hanafee, Burapha Science Journal 17, 142-149 (2012)

8. N. Meein, A. Kunchornrat, T. Tavattana, Journal of Industrial Education 8, 13-23 (2014)

9. W. Parathong, Master Thesis, (2007)

10. S. Tirawanichakul, S. Chanchiew, Y. Tirawanichakul, KKU Research Journal 18, 311. 324 (2013) 